\title{
Analysis of a possible impact of preference for plant species in a rural community in the semi-arid region of Brazil
}

\section{Eduardo Uchôa Guerra Barbosa, José Ribamar Farias Lima, Camilla Marques de Lucena, Thamires Kelly Nunes Carvalho, João Alberto Lins Filho, Mariana Muniz Nunes and Reinaldo Farias Paiva de Lucena*}

Universidade Federal da Paraíba. Centro de Ciências Exatas e da Natureza. Departamento de Sistemática e Ecologia. Laboratório de Etnobiologia e Ciências Ambientais. Cidade Universitária, S/№. João Pessoa-PB, Brasil (CEP 58051-900). *Email: reinadolucena.dr@gmail.com.

\begin{abstract}
The climate change expected for the coming decades it is expected an increase in the number of semi-arid regions worldwide and the frequency of climatic extremes. When climatic changes such as those expected for semi-arid regions occur in a conflict environment with no resilience structure, they can influence how factors that affect the environmental structure may also affect the social structure. To identify how the traditional use of native plant species can be influenced by a change in their availability in a certain area, 26 residents in the semi-arid region, were interviewed. Then, a Use Preference Pressure Index (UPPI) was applied to identify the most used species in the rural community of Santa Rita, located in the semiarid region of Paraíba, Brazil. Sixteen species, classified into nine categories of use, were identified. The species with the highest use preference were sampling through damage analysis, identifying the types of extraction related to the categories used to determine the most worrying issues. The used species also had high potential for other medicinal purposes. The current uses recorded in Santa Rita showed a high potential for adaptation to landscape changes toward the reduction of vegetation loss impacts, as a response to climatic variability.
\end{abstract}

Keywords: Semi-arid; Use evaluation indexes; Traditional knowledge.

Resumo. Análise do possível impacto da preferência por espécies de plantas em uma comunidade rural na região semiárida do Brasil. Com as mudanças climáticas esperadas para as próximas décadas, espera-se um aumento no número de regiões semiáridas em todo o mundo e na frequência de extremos climáticos. Quando mudanças climáticas, como as esperadas para regiões semiáridas, ocorrem em um ambiente de
Received

July 4, 2020

Accepted

October 17, 2020

Available online

October 18, 2020

Released

December 31, 2020

Full Text Article

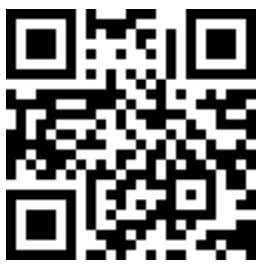

ORCID

(D) 0000-0002-6818-7604

Eduardo Uchôa Guerra

Barbosa

D 0000-0001-5705-0672

José Ribamar Farias

Lima

(D) 0000-0002-5126-8969

Camilla Marques de

Lucena

ISSN 2359-1412/RBGAS-2020-0157/2020/7/17/6/1127

Rev. Bras. Gest. Amb. Sustent.

http://revista.ecogestaobrasil.net 
conflito sem estrutura de resiliência, elas podem influenciar nos fatores que afetam a estrutura ambiental e estrutura social. Para identificar como o uso tradicional de espécies vegetais nativas pode ser influenciado por uma mudança na sua disponibilidade, em uma determinada área, foram entrevistados 26 moradores do semiárido. Em seguida, um Índice de Pressão de Preferência de Uso (IPPU) foi aplicado para identificar as espécies mais utilizadas na comunidade rural de Santa Rita, localizada no semiárido da Paraíba, Brasil. Foram classificadas 16 espécies, distribuídas em nove categorias de uso. As espécies com maior preferência de uso foram amostradas por meio de análise de danos, identificando os tipos de extração relacionados às categorias utilizadas para determinar as questões mais preocupantes. As espécies utilizadas também apresentam alto potencial para outras finalidades medicinais. Os usos atuais registrados em Santa Rita apresentam alto potencial de adaptação às mudanças da paisagem em direção à redução dos impactos da perda de vegetação, em resposta à variabilidade climática.

Palavras-chave: Semiárido; Índices de avaliação de uso; Conhecimento tradicional.
D) 0000-0003-3847-1249 Thamires Kelly Nunes Carvalho

(ㄱ) 0000-0003-1105-7486 João Alberto Lins Filho

D) 0000-0002-9794-124X Mariana Muniz Nunes

D) 0000-0003-4775-7775 Reinaldo Farias Paiva de Lucena

\section{Introduction}

Scientific research in rural communities has been showing more and more strongly that the relationship between human populations and the environment around them goes beyond a simple resource extraction and follows a cultural path in which living beings are described in detail and with a quite strong emotional bond, especially species used daily to support human activities, thus becoming part of the local culture. This representativeness can be observed in constructions originating from ancient customs, which are still maintained, such as the way most localities are delimited, using stake fences, named as "faxina" (Lucena 2009; Nascimento et al., 2009; Lima et al., 2015), which are built of stakes obtained from local plants. This can also be observed in the residences, in the way some animals are raised for food.

In the semi-arid region of Brazil, anthropogenic activities, due to the inappropriate use of resources, have caused environmental damage, almost irreversible, as the desertification process has already affected about $15 \%$ of the Caatinga biome. The consequences of years of predatory extraction are visible such as irrecoverable losses in the flora and fauna diversity, accelerated erosion, and decrease in soil fertility and the amount of water (Schober, 2002). This is evidenced by the fact that 28 animal species of the Caatinga are nationally or globally threatened with extinction (Leal et al., 2005). The remaining vegetation in this biome was $53.62 \%$ in 2008 . The deforestation monitoring in the Caatinga, performed by technicians from the Ministry of Environment (MMA), Brazilian Environmental Protection Agency (IBAMA), and United Nations Development Program (UNDP), recorded a devastated area of $16,576 \mathrm{~km}^{2}$ (2\% of the total vegetation), between 2002 and 2008. Albuquerque and Andrade (2002) mentions that, in northeastern Brazil, the expansion of animal husbandry results in the conversion of forests to pastures and crops. Thus, the conservation of this biological heritage is extremely important.

A logical need for the continued use of a given species in a rural community is its availability in quantity equal to or higher than the demand for resources intrinsic to each 
use or category of use, as recorded by Lima et al. (2015) when evaluating the amount of native wood used in the construction of fences in a rural community.

The relationship between the rural populations' knowledge and the use of useful plant species, above-mentioned, may be influenced by climate change, which is described in the literature as a force capable of transforming a natural landscape (Collins et al., 2013) and causing serious consequences for cultural structures, especially those linked to the environment in a more basic way, through collection relationships and subsistence agriculture, revealing a significant vulnerability of some ecosystems and human systems to current climate change (Field et al., 2014).

The semi-arid region of Brazil can be climatically characterized, for analysis purposes, as other semi-arid regions in the world for which an increase in dry periods and decrease in rainfall have been expected (under the RCP 8.5 scenario) (Collins et al., 2013). These changes have already been perceived by local experts in other parts of the globe, who identify climate change and how it can affect agricultural activities, especially those related to water availability (Barkmann et al., 2017).

Sivakumar et al. (2005) argue that climate is the main source of global fluctuations in food production in arid and semi-arid areas of developing countries. Considering droughts as the main damaging climatic event recorded in the semi-arid region of Brazil, they can be seen not only as a climatic event but also as a socioeconomic phenomenon (Finan and Nelson 2001) capable of shaping culture, environment, politics and social structure (Lemos et al., 2002). Thus, droughts have been identified as the main manifestation of climatic variability in northeastern Brazil, and a possible obstacle to the development of activities in semi-arid regions, contributing to the disarticulation of small producers' living conditions (Marengo 2009).

This study aimed to assess possible pressures on native plant species in a rural community in the semi-arid region of Paraíba, northeastern Brazil. For this purpose, pressures resulting from the preference for the use of some species were identified using an index proposed by Lima (2018). Then, the feasibility of this index was verified for similar regions.

The municipality of Congo was selected as the study area because it is located in a semi-arid region with characteristics similar to other regions in the world threatened by the effects of climate change.

\section{Method}

\section{Study communities}

The Municipality of Congo is located in the Borborema Mesoregion and Cariri Ocidental Microregion (Figure 1), at an approximate altitude of $480 \mathrm{~m}$, between coordinates $7^{\circ} 47^{\prime} 41^{\prime \prime} \mathrm{S}$ and $36^{\circ} 39^{\prime} 42^{\prime \prime} \mathrm{W}$, about $212 \mathrm{~km}$ away from the state capital, João Pessoa. It borders the Municipalities of Brejo de Santa Cruz (Pernambuco State), and Monteiro, Sumé, Serra Branca, Camalaú, Coxixola, and Caraúbas in Paraíba State, with a total population of 4,692 inhabitants (1,748 in rural areas and 2,944 in urban areas) and a territorial area of $333.469 \mathrm{~km}^{2}$, with a population density of 14 inhabitants $/ \mathrm{km}^{2}$ (IBGE 2020). Santa Rita is approximately $8 \mathrm{~km}$ away from the urban center. Its economy is based on subsistence agriculture, especially the cultivation of corn and beans. Goat and sheep breeding is the main community livestock activity; there is also cattle breeding. 


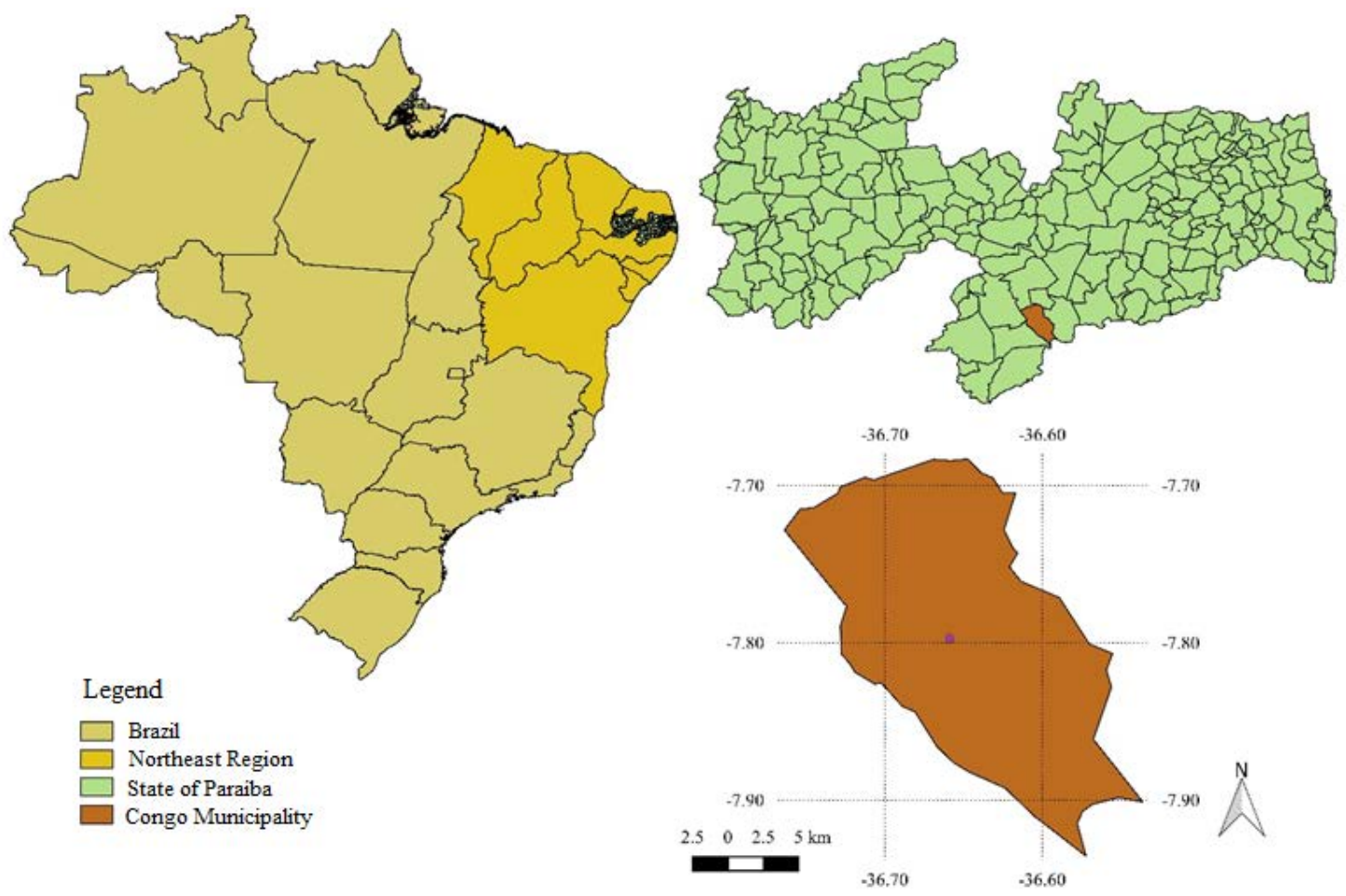

Figure 1. Location of the Municipality of Congo, in the Borborema Mesoregion and the Western Cariri Microregion, in the semiarid region of the State of Paraíba, Northeastern Brazil.

\section{Ethnobotanical data collection}

The ethnobotanical data were obtained through semi-structured interviews with family breadwinners, seeking to reach all families living in the study community (48 residences). As the aim of the research was not related to the distribution of knowledge, it was decided to interview the informants in their residences, even as a couple, in order to identify the uses and knowledge regarding the family structure represented in their homes.

Only current uses of species were recorded, identifying the type of use given to each one and their collection frequency. This study was approved by the Human Research Ethics Committee (CEP) of the Lauro Wanderley Hospital of the Federal University of Paraíba (CEP/HULW No. 297/11). All participants were informed about the research objectives and asked to sign the Informed Consent Form, as required by the National Health Council (Resolution No. 196/1996).

\section{Indication of pressure on plant species caused by a preference for their use}

The pressure on useful plant species, as a result of their current use, was assessed using the Use Preference Pressure Index (UPPI) developed by Lima et al (2018), which considers characteristics of use, frequency of collection, and categories of use of species indicated by the informants. This index has an ethnobotanical character and was obtained through a questionnaire aimed at identifying the species currently used in the community, recording the following information: (1) collection frequency (weekly, monthly, sporadically, or annually) of each species, for each type of use, considering the most cited use; (2) type of damage on the species caused by each use (total or partial extraction, removal of branches, and/or use of leaves or fruit), considering the most cited use; (3) 
number of respondents who cited actual and current uses of each species; and (4) number of use categories in which the species are classified.

Non-numerical variables (frequency of collection and type of damage) were replaced with a numerical rank ranging from 1-4, in which higher values were attributed to higher frequencies and total damage, decreasing from 4-1 (the most harmful damage recorded, i.e., total extraction of the plant, received a score of 4 , and the least harmful damage received a score of 1 ).

According to Lima et al. (2018), this index was developed in order to avoid overlapping variables. The variables were chosen based on the following assumptions: (1) a species is under greater pressure when, for its main form of use, it is necessary to extract the whole plant, consequently causing the specimen's death, which is seen here as damage analysis; and (2) the higher the frequency of use of a species, the higher the pressure on it, which can be increased if the species is classified into more than one use category. The index was established by considering the relationship between the importance of each variable and its observation in the community, represented by the following equation:

$$
\begin{gathered}
U P P I=a_{1} x_{1 n}+a_{2} x_{2 n}+\cdots+a_{k} x_{k n} \\
U P P I=\sum_{i=1}^{k} a_{i} x_{i n}
\end{gathered}
$$

where, $x_{i n}$ is the value of the i-th variable observed for the $\mathrm{n}$-th object and $a_{i}$ is the weight of the i-th variable (importance of each variable in the construction of the index), obtained from Principal Component Analysis (PCA).

\section{Results and discussions}

\section{Determining the UPPI for the study community}

The weighting of variables was performed according to Kubrusly (2001), using the PCA, in which each component was considered as a weight in an index represented by the sum of the variables. The PCA of the specific variables observed in the community resulted in the weights $\left(a_{i}\right)$ shown in the principal component graph (Figure 2).

The weighting of the index components, using results from a PCA, gave rise to the following equation:

$$
\begin{gathered}
\text { UPPI }=(\text { damage } \times 0.717+\text { frequency } \times 0.133+\text { number of users } \times 0.111+ \\
\text { categories of use } \times 0.037) / 100
\end{gathered}
$$

The analysis resulted in a species classification based on the current pressure on the useful plants recorded here. The data on the species phytosociology were not addressed so that the results only showed the preference of use for each species and, consequently, the cultural basis of the use. This decision was made even knowing the theory proposed by Phillips and Gentry (1993), which was tested in other studies (Lima et al., 2016; Lucena et al., 2007; Ribeiro et al., 2014, among others), who propose a direct relationship between use and availability of resources in areas near the communities. 


\section{Principal components}

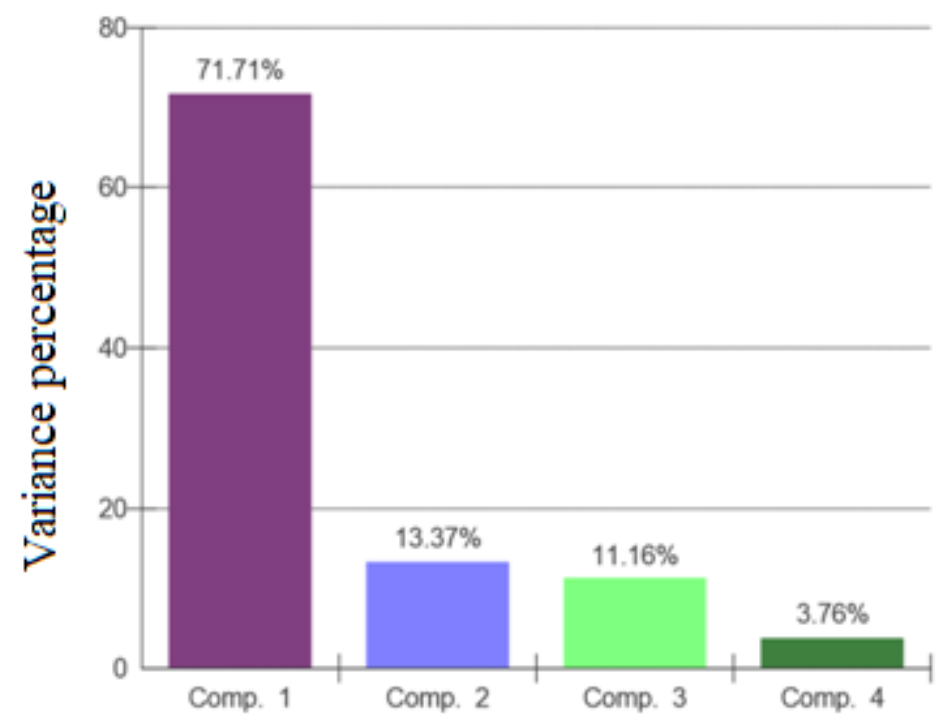

Figure 2. Variance percentage of principal components used to determine the Use Preference Pressure Index (UPPI) for plant species in the community of Santa Rita, located in the municipality of Congo (Paraíba State, northeastern Brazil).

When determining the UPPI, constituent elements are identified. Thus, it was found a higher impact when assessing the type of damage related to the use of species, corroborating the results by Lima et al. (2018). The weights obtained from the PCA made it possible to direct the use of knowledge when characteristics of use were selected in each community.

The versatility of use, in community of Santa Rita, can be seen as the least important characteristic, based on the parameters identified by the UPPI. The Categories grouping, which assesses the way in which the number of uses within different categories of each species has not demonstrated the greatest versatility can lead to a species-specific safeguard process, by using reverse logistics of IPPU studies as a way of analysis.

\section{Use of plant species in the community of Santa Rita}

Sixteen native plant species are actually used in the community of Santa Rita, according to the obtained data (Table 1). The uses were divided into nine categories, as follow: Food (Fo), Fuel (Fu), Construction (Ct), Fodder (Fd), medicinal (Med), Others (Oth), Technology (Tec), Poison/Abortion ( $\mathrm{Po} / \mathrm{Ab}$ ), and veterinary (Vet). The use of native species was recorded in 26 of the visited residences $56.5 \%$ of the residences in the community).

A mean of six species per use category was recorded. Fodder was the most prominent category (11 species), followed by fuel ( 9 species), medicinal, and others (8 species each). The category "others" included shade, magical/religious, and ornamental uses. The species used for these purposes have no need to be cut or removed to another area. Food category had the lowest number of species recorded; only 2 (Spondias tuberosa Arruda and Ziziphus joazeiro Mart.). 
Table 1. Uses of plant species recorded in the rural community of Santa Rita, located in the municipality of Congo (Paraíba, northeastern Brazil).

\begin{tabular}{|c|c|c|c|c|}
\hline Scientific name & $\begin{array}{c}\text { Vernacular } \\
\text { name }\end{array}$ & Category of use* & $\begin{array}{c}\text { Actual } \\
\text { use }\end{array}$ & UPPI \\
\hline \multicolumn{5}{|l|}{ Anacardiaceae } \\
\hline Myracrodruon urundeuva Allemão & Aroeira & Med, Fd, Ct, Fu, Vet, Oth & 6 & 0.0100 \\
\hline Schinopsis brasiliensis Engl. & Baraúna & $\mathrm{Fd}, \mathrm{Tec}, \mathrm{Fu}, \mathrm{Oth}, \mathrm{Po} / \mathrm{Ab}$ & 5 & 0.0180 \\
\hline Spondias tuberosa Arruda & Umbuzeiro & Fo, Fd, Oth & 18 & 0.0179 \\
\hline \multicolumn{5}{|l|}{ Apocynaceae } \\
\hline Aspidosperma pyrifolium Mart. & Pereiro & $\begin{array}{l}\text { Fu, Ct, Tec, Vet, Po/Ab, } \\
\text { Fd, Oth }\end{array}$ & 16 & 0.0162 \\
\hline \multicolumn{5}{|l|}{ Bignoniaceae } \\
\hline $\begin{array}{l}\text { Tabebuia aurea (Silva Manso) } \\
\text { Benth. \& Hook. f. ex S. Moore }\end{array}$ & Craibeira & Tec, Fu, Ct, Fd, Oth & 11 & 0.0193 \\
\hline \multicolumn{5}{|l|}{ Burseraceae } \\
\hline $\begin{array}{l}\text { Commiphora leptophloeos (Mart.) J. } \\
\text { B. Gillet }\end{array}$ & Umburana & Med & 1 & 0.0108 \\
\hline \multicolumn{5}{|l|}{ Euphorbiaceae } \\
\hline Cnidoscolus quercifolius Pohl & Favela & $\mathrm{Po} / \mathrm{Ab}$ & 1 & 0.0085 \\
\hline Manihot cf. dichotoma Ule & Maniçoba & $\mathrm{Po} / \mathrm{Ab}$ & 4 & 0.0158 \\
\hline Croton blanchetianus Baill. & Marmeleiro & $\mathrm{Ct}, \mathrm{Fu}, \mathrm{Fd}, \mathrm{Tec}, \mathrm{Med}$ & 15 & 0.0373 \\
\hline Jatropha mollissima (Pohl) Baill. & Pinhão brabo & Vet, Tec, Med & 4 & 0.0085 \\
\hline \multicolumn{5}{|l|}{ Fabaceae } \\
\hline $\begin{array}{l}\text { Anadenanthera colubrina (Vell.) } \\
\text { Brenan }\end{array}$ & Angico & $\begin{array}{l}\text { Med, Po/Ab, Fd, Fu, Ct, } \\
\text { Tec }\end{array}$ & 7 & 0.0116 \\
\hline Poincianella pyramidalis Tul. & Catingueira & $\mathrm{Fu}, \mathrm{Fd}, \mathrm{Ct}, \mathrm{Med}, \mathrm{Oth}$ & 16 & 0.0288 \\
\hline $\begin{array}{l}\text { Libidibia ferrea (Mart. ex Tul.) L. P. } \\
\text { Queiroz }\end{array}$ & Jucá & Fd, Tec, Med & 5 & 0.0245 \\
\hline $\begin{array}{l}\text { Mimosa ophthalmocentra Mart. ex } \\
\text { Benth. }\end{array}$ & $\begin{array}{l}\text { Jurema de } \\
\text { imbira }\end{array}$ & $\mathrm{Fu}, \mathrm{Fd}, \mathrm{Ct}$ & 3 & 0.0353 \\
\hline Mimosa tenuiflora (Willd.) Poir. & Jurema preta & $\mathrm{Fu}, \mathrm{Fd}, \mathrm{Vet}, \mathrm{Ct}, \mathrm{Tec}, \mathrm{Oth}$ & 16 & 0.0087 \\
\hline \multicolumn{5}{|l|}{ Rhamnaceae } \\
\hline Ziziphus joazeiro Mart. & Juazeiro & Med, Fd, Fo, Oth & 14 & 0.0091 \\
\hline
\end{tabular}

${ }^{*}$ Food = Fo; Fuel = Fu; Construction = Ct; Fodder = Fd; Medicinal = Med; Others = Oth; Technology = Tec; Poison/Abortion = Po/Ab; and Veterinary $=$ Vet.

The results regarding the use of species were similar to those recorded by Lima et al. (2018) when they used the UPPI in a rural community in the municipality of Cabaceiras, also located in the semi-arid region of Paraíba. These authors observed a higher use preference by informants who cited a mean of 8.1 species per residence. M. urundeuva, S. obtusifolium, A. pyrifolium, P. pyramidalis, S. tuberosa, and M. tenuiflora were recorded as the most preferred species.

\section{Types of use vs UPPI}

The highest number of categories was found for A. pyrifolium, with actual uses recorded in seven categories and 16 of the residences. This species versatility is accompanied by uses in categories that require the removal of a large part of the plant, or that cause specimens' death. This species is mainly used for fuel and construction purposes, according to the respondents. There are several current and very relevant records regarding the medicinal use of $A$. pyrifolium; however, no medicinal use was recorded for this species in the community of Santa Rita. Ceravolo et al. (2018) and Araújo et al. (2018) corroborate medicinal uses for A. pyrifolium by cytochemical analysis, which, 
with due parsimony, could contribute to modify the uses of this plant in rural communities (Araújo et al., 2018; Ceravolo et al., 2018).

Among the most used plants, P. pyramidalis, M. tenuiflora, and C. blanchetianus were the main species recorded for fuel and construction purposes, with actual uses mentioned in 16, 16, and 15 residences, respectively. The medicinal category recorded for $P$. pyramidalis and $C$. blanchetianus has been seen as significant potential use. Recent studies on the use of chemical extracts from these two species were published by Firmino et al. (2018, 2019), respectively (Firmino et al., 2018, 2019). Their results indicate potential uses that can contribute to the development of conservation measures for such species, mainly because of the low damage caused by the extraction of leaves or bark, which are the main plant parts used for medicinal purposes.

The species versatility associated with the UPPI is not a direct relationship that can be analyzed, according to the data used to determine the UPPI for the study community. Despite this information and several uses, some plants with a higher UPPI are on the list of versatile species. The high number of uses gains importance due to the grouping of uses with higher harmful potential, such as the use as fuel. The versatility in the use of species, by applying the UPPI, would be observed in the index determination when verifying its distribution, which is the major characteristic of categories, identifying them as a character of relatively greater weight.

Despite the use versatility is not identified as a key element for local uses, the indication of highly versatile species, such as $M$. urundeuva, with a high number of uses, has been recorded in other studies (Lucena et al., 2011; Santos et al., 2018). These authors, concerning such use profiles, found a strong tendency toward the medicinal use of this species. In Santa Rita, M. urundeuva was also the species most cited in this category. Matos et al. (2019) also recorded therapeutic uses of this species, emphasizing that its use in alcoholic extracts can affect human bone structure due to oxidative stress. Souza et al. (2019) pointed out the high economic and cultural importance of M. urundeuva in Brazil, and, addressing the fact it is highly threatened with extinction, defended the development of microsatellite genetic markers as a way to assist in the protection of genetic information of this species (Souza et al., 2018).

UPPI Standard Deviation

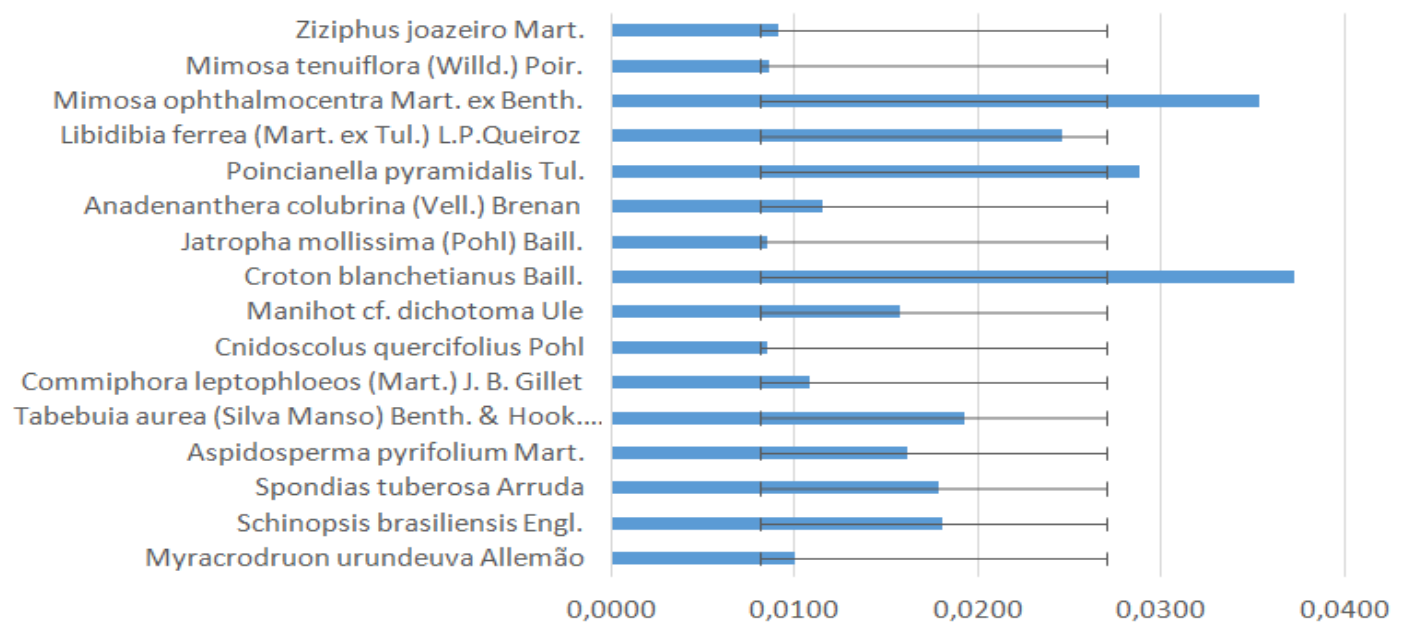

Figure 3. UPPI standard deviation for plant species used in the community of Santa Rita, located in the municipality of Congo (Paraíba, northeastern Brazil). 
The UPPI distribution recorded in Santa Rita deviated considerably from the mean data, as can be shown in Figure 3. Regarding the deviation in the use of species, M. ophtalmocentra and C. blanchetianus had above-average dispersion values. The heterogeneous distribution of pressure indicated by the standard deviation evidences a higher use pressure on species. These are key values for the conservation of species, as well as of a culture associated with their uses.

Nogueira et al. (2018) recorded initial germination potential in seeds of M. ophtalmocentra in soils with saline tendency and high-temperature areas (around $30^{\circ} \mathrm{C}$ ). In this context, this species gains a high potential significance when considering germination in environments with global temperature variation according to what was predicted by Collins et al. (2013), or in areas with poor soil or initial desertification processes (Collins et al., 2013).

\section{Conclusion}

Based on the availability of useful plant resources in the community of Santa Rita, the respondents prefer to use species considered more versatile. The low versatility of uses recorded in the community can be a worrying factor given the high presence of harmful uses.

The analysis of the possible impact on species in Santa Rita allowed us to assess that the pressure on plants is related to more harmful uses, such as timber uses, for which the whole plant is used, causing the specimen's death or removal of most of the vegetative structure. When associating the uses with an indication of versatility, it can be concluded that a more comprehensive knowledge of biological, chemical, and physical characteristics of the used species, as well as of the needs of use recorded in each residence, can serve as a guiding element for the use of species in contingency plans for environmental resources to maintain the vegetation structure during the time necessary for the recovery of species more likely to suffer greater damage.

It is worth mentioning that the development of some type of plan for the management and protection of native vegetation, in the semi-arid region of Paraíba, must consider not only indexes developed to understand the uses and ethnobotanical knowledge of plant species, but they also need to be based on the identification of environmental problems related to grazing (by goats, sheep, and cattle), historical land use characteristics, and the consequent process of desertification or less substantial degradation of soils but still capable of affecting the virtual distribution of plant species.

The results also showed a predominance of caatinga pioneer species (e.g. C. blanchetianus, P. pyramidalis, A. pyrifolium, and M. tenuiflora.) in the study community. Climax species such as $M$. urundeuva and $S$. brasiliensis are rare, even though they are mentioned as used by the local population, which denotes the "import" of products derived from these and other plants and the degradation level of the original vegetation. The pioneer species above-mentioned are characterized by high resistance to anthropization and droughts, although these two factors, acting together, can threaten even these plants.

In the case of $A$. pyrifolium, perhaps its predominant use by the local population is related to its significant occurrence in the study area and because there are no longer species more appropriate for the form of use chosen by the residents. This is an issue for future research.

How the UPPI was used to identify current characteristics is another factor that should be considered in the general analysis of possible uses of this index. This research brings a point of view that can be implemented when comparing UPPI data and its current database with possible information that may give the index a view of potential uses. Thus, it is suggested future studies aimed at analyzing how the use pressure on a species may

Rev. Bras. Gest. Amb. Sustent., 2020, vol. 7, n. 17, p. 1127-1138. 
have been modified over time. This data may show the evolution in the use of some species and its cultural construction.

\section{Conflict of interests}

The authors declare that they do not have any conflict of interests.

\section{Referências}

Albuquerque, U. P.; Andrade, L. H. C. Conhecimento botânico tradicional e conservação em uma área de Caatinga no Estado de Pernambuco, Nordeste do Brasil. Acta Botanica Brasilica, v. 16 , no. 3 , p. $273-285$, 2002. https://doi.org/10.1590/S010233062002000300004

Araújo, D. P.; Nogueira, P. C. N.; Santos, A. D. C.; Costa, R. O.; Lucena, J. D.; Gadelha-Filho, C. V. J.; Lima, F. A. V.; Neves, K. R. T.; Leal, L. K. A. M.; Silveira, E. R.; Viana, G. S. B. Aspidosperma pyrifolium Mart: Neuroprotective, antioxidant and anti-inflammatory effects in a Parkinson's disease model in rats. Journal of Pharmacy and Pharmacology, v. 70, No. 6, p. 787-796, 2018. https://doi.org/10.1111/jphp.12866

Barkmann, T.; Siebert, R.; Lange, A. Land-use experts' perception of regional climate change: An empirical analysis from the North German Plain. Climatic Change, v. 144, No. 2, p. 287-301, 2017. https://doi.org/10.1007/s10584-017-2041-x

Ceravolo, I. P.; Zani, C. L.; Figueiredo, F. J. B.; Kohlhoff, M.; Santana, A. E. G.; Krettli, A. U. Aspidosperma pyrifolium, a medicinal plant from the Brazilian caatinga, displays a high antiplasmodial activity and low cytotoxicity. Malaria Journal, v. 17, No. 1, p. 1-11, 2018. https://doi.org/10.1186/s12936-018-2568-y

Collins, M.; Knutti, R.; Arblaster, J.; Dufresne, J.-L.; Fichefet, T.; Friedlingstein, P.; Gao, X.; Gutowski, W. J.; Johns, T.; Krinner, G.; Shongwe, M.; Tebaldi, C.; Weaver, A. J.; Wehner, M. F.; Allen, M. R.; Andrews, T.; Beyerle, U.; Bitz, C. M.; Bony, S.; Booth, B. B. B. Long-term climate change: Projections, commitments and irreversibility. Cambridge: Cambridge University Press, 2013. Available from: <https://research.monash.edu/en/publications/ long-term-climate-change-projections-commitments-and-irreversibil>. Accessed on: Jun. 30, 2020.

Field, C. B.; Barros, V.; Mach, K.; Mastrandrea, M.; Aalst, M.; Adger, N.; Arent, D. J.; Barnett, J.; Betts, R.; Bilir, E.; Birkmann, J.; Carmin, J.; Chadee, D.; Challinor, A.; Chaterjee, M.; Cramer, W.; Davidson, D.; Estrada, Y.; Gatusso, J.-P.; Hijioka, Y.; Yohe, G.; Hiza, M.; HoeghGuldberg, O.; Huang, H.-Q.; Insarov, G.; Jones, R.; Kovats, S.; Lankao, P. R.; Larsen, J. N.; Losada, I.; Marengo, J.; McLean, R.; Mearns, L.; Mechler, R.; Morton, J.; Niang, I.; Oki, T.; Olwoch, J. M.; Opondo, M.; Poloczanska, E.; Pörtner, H.-O.; Reisinger, A.; Revi, A.; Schmidt, D.; Shaw, R.; Solecki, W.; Stone, D; Stone, J.; Strzepek, K.; Suarez, A. G.; Tschakert, P.; Valentini, R.; Vicuna, S.; Villamizar, A.; Vincent, K.; Warren, R.; White, L.; Wilbanks, T.; Wong, P. P. Climate Change 2014: Technical summary. In: Field, C. B.; Barros, V. R.; Dokken, D. J.; Mach, K. J.; Mastrandrea, M. D.; Bilir, T. E.; Chatterjee, M.; Ebi, K. L.; Estrada, Y. O.; Genova, R. C.; Girma, B.; Kissel, E. S.; Levy, A. N.; MacCracken, S.; Mastrandrea, P. R.; White, L. L. Climate Change 2014: Impacts, adaptation, and vulnerability. Part A: Global and sectoral aspects. Contribution of Working Group II to the Fifth Assessment Report of the Intergovernmental Panel on Climate Change. Cambridge: Cambridge University Press, 2014. p. 35-94. 
Finan, T.; Nelson, D. Making rain, making roads, making do: Public and private adaptations to drought in Ceará, Northeast Brazil. Climate Research, v. 19, No. 2, p. 97-108, 2001. https://doi.org/10.3354/cr019097

Firmino, N. C. S.; Alexandre, F. S. O.; Vasconcelos, M. A.; Conrado, A. J. S.; Arruda, F. V. S.; Silveira, E. R.; Teixeira, E. H. Antimicrobial activity of 3,4-seco-diterpenes isolated from Croton blanchetianus against Streptococcus mutans and Streptococcus parasanguinis. Journal of Brazilian Chemical Society, v. 29, No. 4, p.814-822, 2018. https://doi.org/10.21577/0103-5053.20170204

Firmino, N. C. S.; Alexandre, F. S. O.; Vasconcelos, M. A.; Pinheiro, A. A.; Arruda, F. V. S.; Guedes, M. L. S.; Silveira, E. R.; Teixeira, E. H. Diterpenes isolated from Croton blanchetianus Baill: Potential compounds in prevention and control of the oral streptococci biofilms. Industrial Crops and Products, v. 131, p. 371-377, 2019. https://doi.org/10.1016/j.indcrop.2019.01.062

IBGE - Instituto Brasileiro de Geografia e Estatística. Brasil, Paraíba, Congo. 2010. Available from: <https://cidades.ibge.gov.br/brasil/pb/congo/panorama>. Accessed on: July 1, 2020.

Kubrusly, L. S. Um procedimento para calcular índices a partir de uma base de dados multivariados. Pesquisa Operacional, v. 21, No.1, p.107-117, 2001. https://doi.org/10.1590/s0101-74382001000100007

Leal, I. R.; Maria da Silva, J. C.; Tabarelli, M.; Lacher Jr, T. E. Mudando o curso da conservação da biodiversidade na Caatinga do Nordeste do Brasil. Megadiversidade, v. 1, No. 1, p. 139-146, 2005.

Lemos, M. C.; Finan, T. J.; Fox, R. W.; Nelson, D. R.; Tucker, J. The use of seasonal climate forecasting in policymaking: Lessons from Northeast Brazil. Climatic Change, v. 55, No. 4, p. 479-507, 2002. https://doi.org/10.1023/A:1020785826029

Lima, J. R. F. 0 capital humano no processo de adaptação às variações climáticas no semiárido paraibano. João Pessoa: Universidade Federal da Paraíba, 2018. (Dissertação de mestrado).

Lima, J. R. F.; Alves, C. A. B.; Ribeiro, J. E. S.; Cruz, D. D.; Mourão, J. S.; Torre Cuadros, M. L. A.; Lucena, R. F. P. Uso e disponibilidade de espécies vegetais nativas no semiárido do nordeste do Brasil: uma análise da hipótese da aparência ecológica. REDE - Revista Eletrônica do PRODEMA, v. 10, No. 1, p. 110-131, 2016.

Lima, J. R. F.; Nascimento Filho, A. H.; Alves, C. A. B.; Nascimento, V. T.; Mourão, J. S.; Oliveira, R. S.; Lucena, R. F. P. Uso y manejo de cercas en una comunidad rural. Interciencia, v. 40, No. 9, p. 618-625, 2015.

Lucena, R. F. P.; Araújo, E. L.; Albuquerque, U. P. Does the local availability of woody Caatinga plants (Northeastern Brazil) explain their use value. Economic Botany, v. 61, No. 4, p. 347-361, 2007. https://doi.org/10.1663/00130001(2007)61[347:DTLAOW]2.0.C0;2

Lucena, R. F. P. Avaliando a eficiência de diferentes técnicas de coleta e análise de dados para a conservação da biodiversidade a partir do conhecimento local. Recife: Universidade Federal Rural de Pernambuco. 2009. (Tese de doutorado).

Lucena, R. F. P.; Farias, D. C.; Carvalho, T. K. N.; Lucena, C. M.; Vasconcelos Neto, C. F. A.; Albuquerque, U. P. Uso e conhecimento da aroeira (Myracrodruon urundeuva) por comunidades tradicionais no Semiárido brasileiro. Sitientibus série Ciências Biológicas, v. 11, No. 2, p. 255-264, 2011. 
Marengo, J. A. Vulnerability, impacts and adaptation (VIA) to climate change in the semiarid region of Brazil. In: Poppe, M. K. (Coord.). Brazil and climate change: vulnerability, impacts and adaptation. Brasília: CGEE, 2009. p.137-146. Available from: <https://www.cgee.org.br/documents/10182/734063/9Livro+2009_Climate+Changes_fi nal_6411.pdf>. Accessed on: July 1, 2020.

Nascimento, V. T.; Sousa, L. G.; Alves, A. G. C.; Araújo, E. L.; Albuquerque, U. P. Rural fences in agricultural landscapes and their conservation role in an area of caatinga (dryland vegetation) in northeast Brazil. Environment, Development and Sustainability, v. 11, No. 5, p. 1005-1029, 2009. https://doi.org/10.1007/s10668-008-9164-1

Nogueira, N. W.; Torres, S. B.; Freitas, R. M. O.; Santos, P. C. S.; Sá, F. V. S.; Leite, M. S. Salt stress and temperatures on the germination and initial growth of "jurema-de-embira" (Mimosa ophthalmocentra) seedlings. Revista Brasileira de Engenharia Agrícola e Ambiental, $\quad$ v. 22, No. 4, p. 273-278, 2018. https://doi.org/10.1590/18071929/agriambi.v22n4p273-278

Phillips, O.; Gentry, A. H. The useful plants of Tambopata, Peru: I. Statistical hypotheses tests with a new quantitative technique. Economic Botany, v. 47, No. 1, p. 15-32, 1993. https://doi.org/10.1007/BF02862203

Ribeiro, J. E. S.; Carvalho, T. K. N.; Alves, C. A. B.; Ribeiro, J. P. O.; Guerra, N. M.; Pedrosa, K. M.; Silva, N.; Sousa Júnior, S. P.; Nunes, A. T.; Souto, J. S.; Lima, J. R. F.; Oliveira, R. S.; Lucena, R. F. P. Ecological apparency hypothesis and availability of useful plants: Testing different use values. Ethnobotany Research and Application, v. 12, p. 415-432, 2014.

Santos, M. O.; Ribeiro, D. A.; Macêdo, D. G.; Macêdo, M. J. F.; Macedo, J. G. F.; Lacerda, M. N. S.; Macêdo, M. S.; Souza, M. M. A. Medicinal plants: Versatility and concordance of use in the caatinga area, Northeastern Brazil. Anais da Academia Brasileira de Ciência, v. 90, No. 3, p. 2767-2779, 2018. https://doi.org/10.1590/0001-3765201820170594

Sivakumar, M. V. K.; Das, H. P.; Brunini, O. Impacts of present and future climate variability and change on agriculture and forestry in the arid and semi-arid tropics. Climatic Change, v. 70, No. 1/2, p. 31-72, 2005. https://doi.org/10.1007/s10584-005-5937-9

Souza, D. C. L.; Rossini, B. C.; Souza, F. B.; Sebbenn, A. M.; Marino, C. L.; Moraes, M. L. T. Development of microsatellite markers for Myracrodruon urundeuva (F.F. \& M.F. Allemão), a highly endangered species from tropical forest based on next-generation sequencing. $\begin{array}{lllll}\text { Molecular Biology Reports, } & \text { v. 45, } & \text { No. 1, } & \text { p.71-75, }\end{array}$ https://doi.org/10.1007/s11033-017-4142-z

License information: This is an open-access article distributed under the terms of the Creative Commons Attribution License, which permits unrestricted use, distribution, and reproduction in any medium, provided the original work is properly cited. 